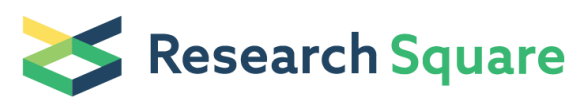 \\ Preprints are preliminary reports that have not undergone peer review. \\ They should not be considered conclusive, used to inform clinical practice, \\ or referenced by the media as validated information.
}

\section{Salinity reduces coastal marsh respiration more than photosynthesis}

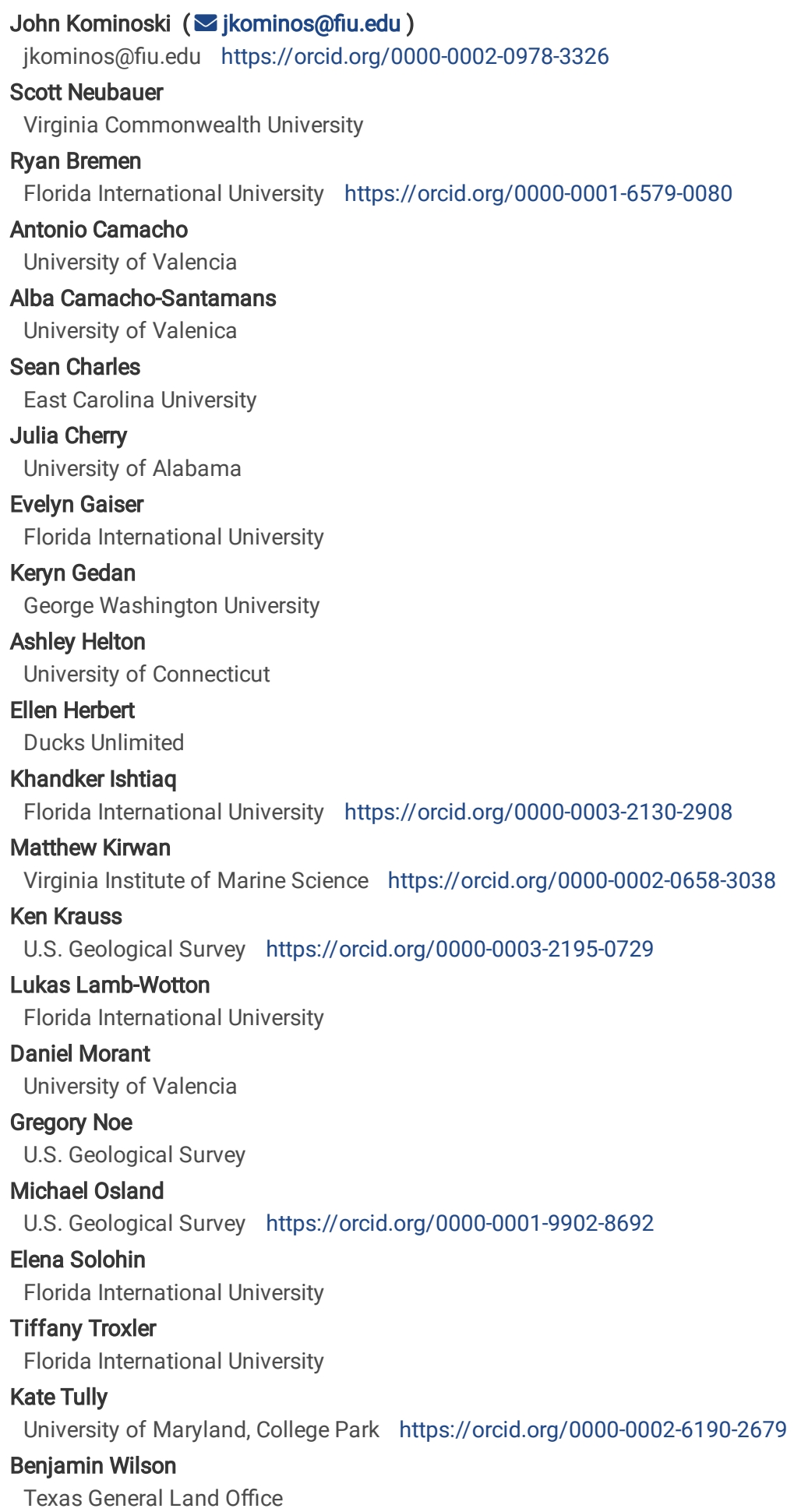


DOI: https://doi.org/10.21203/rs.3.rs-880205/v1

License: @ (i) This work is licensed under a Creative Commons Attribution 4.0 International License. Read Full License 


\section{Abstract}

A paradigm in carbon cycling science predicts that sea-level rise will enhance carbon accumulation in an apparent negative carbon-climate feedback 1,2 . However, ecosystems exposed to combinations of stressors and subsidies - such as saltwater intrusion and sea-level rise - may adapt, transition to an alternative state, or experience a decline in functions, such as carbon storage, thereby altering their response trajectories to environmental changes 3,4 . Climate change is increasing salinity in coastal ecosystems worldwide yet the effects on ecosystem metabolism remain uncertain4-8. Here, we synthesized gross ecosystem productivity (GEP), ecosystem respiration [CO2 and $\mathrm{CH} 4$ (ERCO2 and ERCH4)], and net ecosystem productivity (NEP) from diverse coastal marshes exposed to experimental additions and observational gradients in salinity. Increases in salinity generally caused decreases in median GEP, ERCO2, and ERCH4 but increases in GEP and NEP from 5 to 10 ppt. Increased saltwater intrusion can stimulate or stress wetlands based on relative exposure and acclimation to increased salinities, and we detected positive NEP where salinity increases had greater negative effects on ERCO2 and ERCH4 than GEP. Although increases in NEP are detectable at low salinities, saltwater intrusion and climate-driven disturbances may reduce carbon storage capacity of coastal ecosystems as productivity declines toward higher salinities.

\section{Main}

An emerging paradigm in carbon cycling science has been that vegetated coastal ecosystems sequester disproportionately more carbon than their terrestrial counterparts, and that sea-level rise will enhance carbon accumulation in an apparent negative carbon-climate feedback ${ }^{1,2}$. Perturbation theory predicts that beneficial inputs or subsidies (e.g., nutrients, sediments) enhance ecosystem function at low levels of exposure, but can diminish function at higher levels of exposure, with toxic inputs or stressors having immediate adverse effects on ecosystem function ${ }^{3}$. However, ecosystems exposed to combinations of stressors and subsidies - such as saltwater intrusion and sea-level rise - may adapt, transition to an alternative state, or experience a decline in functions, such as carbon storage, thereby altering their response trajectories to environmental changes ${ }^{3,4}$. Sea-level rise is a global phenomenon that is rapidly increasing saltwater intrusion in many coastal ecosystems ${ }^{4}$. Low-lying coastal ecosystems are exceptionally vulnerable to sea-level rise, changing salinity, and hydrological alterations, all of which influence their persistence through changes in metabolic and geomorphic processes ${ }^{4,5}$. As such, coastal wetlands can be exceptionally vulnerable to sea-level rise, changing salinity, and hydrological alterations, which influence their persistence by inducing changes in metabolic processes. Coastal wetland ecosystems are important global carbon sinks that are threatened - and in many cases rapidly declining - due to climate change, land-use change, and interactions of both as saltwater intrusion becomes more acute from sea-level rise ${ }^{6-8}$. Coastal ecosystem persistence in the face of sea-level rise and saltwater intrusion will be determined by how changes to key metabolic processes influence net ecosystem carbon storage ${ }^{9,10}$. Previous measurements of localized, coastal wetland ecosystem productivity often have found disparate effects of elevated salinity - from actual or experimental saltwater intrusion - on photosynthesis and respiration pathways (Table S1). This is understandable given how adaptations to salinity exposure are expected to be driven by legacy conditions (i.e., whether the wetland has previously been exposed to salinity) and the responses of dominant species (i.e., which change with small increments in salinity), relative to other factors that influence rates of net ecosystem productivity and carbon storage. However, unlike other climate changes drivers such as temperature, which has known sensitivity differences for photosynthesis and respiration ${ }^{11}$, the sensitivity of ecosystem metabolism to saltwater intrusion is largely unknown. Even less is known about how exposure to elevated salinity in lower salinity wetlands - expected with saltwater intrusion and reductions in fresh water - affects net ecosystem productivity.

A synthesis of metabolic responses to changes in salinity across diverse coastal wetlands is critical to reveal generalizable patterns of photosynthetic and respiratory ecosystem responses to saltwater intrusion. Here, we synthesized results from across diverse coastal marsh ecosystems (Fig. 1) that included tidal and non-tidal freshwater, brackish, and salt marshes spanning a subtropical to temperate latitudinal gradient $\left(25^{\circ} \mathrm{N}\right.$ to $\left.52^{\circ} \mathrm{N}\right)$. We examined the following questions: (1) How does increasing salinity differentially affect net ecosystem productivity [NEP = gross ecosystem productivity (GEP) - ecosystem respiration [as carbon dioxide $\left(\mathrm{ER}_{\mathrm{CO} 2}\right)$ and methane $\left(\mathrm{ER}_{\mathrm{CH} 4}\right)$ ] fluxes among coastal marsh ecosystems?, (2) Are there threshold concentrations of salinity that emerge when comparing differential responses to ambient and elevated salinity exposures from experimental salinity additions and along observational salinity gradients?, and (3) What plant-soil mechanisms might explain differential ecosystem metabolic responses to elevated salinities? We predicted that marshes exposed to experimental salinity additions would have higher sensitivity to increases in salinities compared to marshes occurring along observational salinity gradients due to differences in exposure and acclimation.

\section{Marsh ecosystem metabolic rates}

Examination of metabolic trends show strong wide variation among median values of daily $\mathrm{GEP}_{\text {, }} \mathrm{ER}_{\mathrm{CO} 2}$, $\mathrm{ER}_{\mathrm{CH} 4}$, and $\mathrm{NEP}$ at low concentrations of salinity and sharp decreases above 2-10 ppt (Figs. 2A-2D). Patterns of median percent differences of changes in specific metabolic parameters from experimental salinity additions and along observational salinity gradients were distinctly different. Within experimental salinity additions (range $\sim 0$ to 15 ppt), median GEP, ER $\mathrm{CO}_{2}, \mathrm{ER}_{\mathrm{CH} 4}$, and NEP were generally reduced with increased in salinity, but GEP and NEP increased with increases in salinity (from 5 to $10 \mathrm{ppt}$ ) before reaching a threshold and declining above higher increases in salinity concentrations (Figs. 3A-3D). Small increases in salinity resulted in lower $\mathrm{ER}_{\mathrm{CH} 4}$ from experimental salinity additions (Fig. 3C). Along observational salinity gradients (range $\sim 0$ to $30 \mathrm{ppt}$ ), effects of salinity concentrations resulted in lower median GEP, ER $\mathrm{CO}_{\mathrm{C} 2}$, and $\mathrm{ER}_{\mathrm{CH} 4}$ (Figs. 3E-3G). However, NEP increased from low-to-moderate salinity concentrations before reaching a threshold ( $10 \mathrm{ppt})$ and declining above higher salinity concentrations (Fig. $\mathbf{3 H}$ ). Increased salinity resulted in large and abrupt decreases in $\mathrm{ER}_{\mathrm{CO} 2}$ and consistent reductions in $\mathrm{ER}_{\mathrm{CH} 4}$ along observational salinity gradients (Fig. 3G). Along observational salinity gradients, NEP increased with increasing salinity, but NEP generally decreased when salinity was experimentally added (Figs. 3D, 3H). Median NEP increased with 
salinity concentrations from 5 to 10 ppt before reaching a threshold ( 10 ppt) and declining above higher salinity concentrations (Figs. 3D, 3H). Although salinity decreases absolute marsh productivity, low-to-moderate increases in salinity may impact photosynthesis and respiration different. When comparing percent differences in median ecosystem metabolic rates between ambient and elevated salinity conditions from across all studies, we found GEP may be stimulated at lower increases in salinity (Fig. 4A) compared to persistent or steady declines in $\mathrm{ER}_{\mathrm{CO} 2}$ and $\mathrm{ER}_{\mathrm{CH} 4}($ Figs. $4 \mathrm{~B}$, 4C). We found weak evidence for overall effects of increases in salinity on NEP (Fig. 4D), which is likely explained by high variability in percent differences in NEP.

\section{Saltwater subsidies and stressors in coastal marshes}

Despite contrasting observations from previous, site-specific experiments, we find that the response of coastal marsh ecosystem productivity to salinization is predictable and generalizable across fundamentally different marshes around the globe. Overall, we find a nonlinear response where productivity is maximized at an increase in salinity of $10 \mathrm{ppt}$. Our synthesis has identified that NEP increases up to a salinity threshold range, beyond which ecosystem productivity decreases despite the combinations of plant species and hydroperiods surveyed. Given the diversity of sites selected in our synthesis (climate, geography, hydrology, dominant vegetation), site-specific responses to elevated salinities were variable in magnitude and direction (Table S1). The subsidy-stress framework of perturbation theory predicts stress causes immediate and sustained decreases in ecosystem functions and subsidies cause an increase in function at lower levels of a subsidy until a threshold is reached ${ }^{3}$. Our synthesis - using median of long-term rates across a range of salinities - indicates that saltwater intrusion into coastal marsh ecosystems can act as a both a stress and a subsidy, stress to GEP and NEP may be overcome at low levels of salinity with apparent subsidies of saltwater, whereas salinity stress to $\mathrm{ER}_{\mathrm{CO} 2}$ and $\mathrm{ER}_{\mathrm{CH} 4}$ is sustained. Our synthesis also revealed that theoretical expectations for how climate drives metabolism, such as the temperature sensitivity ecosystem respiration and photosynthesis ${ }^{11}$, must be further expanded to better predict how effects of temperature-driven increases in sea-level rise and saltwater intrusion will impact ecosystem metabolic rates. We expected marshes exposed to experimental salinity additions would have higher sensitivity to changes in salinities compared to marshes occurring along observational salinity gradients due to differences in exposure and acclimation, but we observed sensitivity to increases in salinity across all marshes. Our findings suggest that coastal wetland ecosystems may exhibit some adaptive responses to increases in salinity at low-to-moderate salinity concentrations.

Increased salinity appears to stimulate wetland net ecosystem productivity through greater negative effects on ecosystem respiration than photosynthesis (Figs. 3, 4). Saltwater intrusion increases electron acceptors that oxidize reduced wetland conditions and likely stimulates ecosystem productivity in lower salinity wetlands, despite the negative effect of salinity stress on plant primary productivity ${ }^{8}$ (Fig. 5). For example, sulfate increases with saltwater intrusion, and sulfate reduction is more energetically favorable that $\mathrm{CO}_{2}$ reduction to $\mathrm{CH}_{4}$ (methanogenesis) ${ }^{8}$. Ecological theory as well as results from our synthesis suggest that methanogens are displaced by sulfate reducers as the main heterotrophs degrading organic matter under low redox anaerobic conditions 8,12 (Figs. 3,4). Saltwater exposure increases soil porewater salinity, as well as alkalinity and concentrations of ions that can release nutrient subsidies in coastal wetlands $8,12,13$. As changes in ionization and alkalinization occur along with both subsidies and stressors, this likely explains our observations of apparent acclimation of GEP and $\mathrm{ER}_{\mathrm{CO} 2}$ to low-to-moderate increases in saltwater concentrations (Figs. 3, 4). Overall, salinity inhibited ER (both $\mathrm{CO}_{2}$ and $\mathrm{CH}_{4}$ ) more than $\mathrm{GEP}$ in both experimental salinity additions and observational salinity gradients, which resulted in stimulated NEP at lower salinity concentrations (Figs. 3, 4).

Ecosystems that become salinized or oxygen-depleted from prolonged inundation can experience plant dieback, leading to loss of soil aggregates, increased erosion, and loss of production ${ }^{14,15}$. Wetland plant roots exposed to elevated salinity can lose biomass, especially of fine roots, which also results in soil elevation loss and reduced dissolved and particulate carbon export ${ }^{16,17}$. Further acceleration of soil carbon loss can occur from the production of labile detrital carbon from dying plant material, which can be exacerbated by concomitant changes in porewater and surface water nutrients and redox conditions ${ }^{8,14}$. Saltwater intrusion may alter dissolved organic carbon concentrations through physical interactions between cations and dissolved organic matter ${ }^{18}$ or through loss of fine root biomass, soil compression, and release of dissolved organic carbon from soil ${ }^{16,17}$. Changes in carbon and nutrient concentrations may result in saltwater-induced changes in land-ocean biogeochemical fluxes, as well as shifts in the landatmosphere exchange of greenhouse gases $4,19,20$. Soil organic matter processing is altered by exposure to seawater. For example, higher surface litter breakdown rates may occur with increased nutrient concentrations, release of labile forms of carbon, and increased surface and porewater oxidation ${ }^{14,21}$. Saltwater intrusion releases soil-bound nutrients through cation exchange, desorption, or increased rates of litter decomposition ${ }^{4,8,13}$, and nutrient subsidies may alleviate short-term, pulsed salinity stress associated with saltwater intrusion ${ }^{38}$ (Fig. 5), but continued saltwater exposure decreases plant root biomass and leads to soil elevation loss ${ }^{16}$.

\section{Adaptations to saltwater intrusion}

How local ecosystems respond to increasing salinization will be influenced by prior salinity exposure and salinity tolerance of existing plant and soil microbial communities. Plant and microbial compositional shifts can have larger effects on carbon cycling than the direct influence of seawater. Temperate tidal freshwater marshes are expected to transition to brackish or salt marshes where plant communities can migrate upstream with sea-level rise and saltwater intrusion 6,22 . In the transition from tidal freshwater herbaceous plants to salt-tolerant marsh graminoids, the lignin-rich grasses slow decay, despite a positive direct effect of salinity 21,22 . Marsh salinization generally decreases plant and microbial species diversity ${ }^{21}$, and the capacity and type of community shifts depend upon the relative amount of saltwater intrusion, the degree of sulfidation (iron-sulfur buffering) and sensitivity to

salinity, and legacies of land use $\mathrm{e}^{8,22-24}$. In subtropical and tropical coastal wetlands, mangroves are expanding - latitudinally ${ }^{25,26}$ and landward ${ }^{27}$ with rising temperatures and rising seas - into marsh-dominated wetlands. This functional shift from herbaceous and succulent marshes to woody 
mangrove swamps is a major and global transformation that can provide stability and, in the case of landward migration, may provide a pathway toward enhanced accretion and carbon storage compared to coastal freshwater marshes ${ }^{28}$. A similar transition in abandoned, salinized agricultural lands, initially to woody shrublands ${ }^{29}$, could also provide greater opportunity for carbon storage. Where tidal freshwater forested wetlands transition to herbaceous marsh, the opposite trend is expected, particularly if there is not a landward movement of forested wetland habitat upstream ${ }^{29}$. In the face of uncertain effects on carbon storage with increasing saltwater intrusion and the potential for freshwater wetland peat collapse, coastal wetland persistence may increasingly depend on how quickly salt-tolerant plants (i.e., mangroves and salt marsh graminoids) are able to move landward into freshwater and upland ecosystems.

\section{Saltwater intrusion and coastal carbon storage}

Saltwater intrusion is increasing worldwide with rapidly rising sea levels, requiring a broader understanding of the consequences for coastal communities and ecosystems. Site-specific studies have recorded varying productivity responses to elevated salinity despite decreases in soil carbon

storage in coastal wetlands ${ }^{4,12-17}$. Reduced plant biomass and growth, and increased soil organic matter processing and export will contribute to carbon losses. Saltwater intrusion can decrease carbon storage in non-acclimated coastal wetland ecosystems and can increase both carbon and nutrient export. To further identify how vulnerability to carbon loss will vary in coastal wetlands requires a stronger mechanistic understanding of how climate change and land-use legacies will interact with salinizing conditions across that vary in prior exposure and sensitivity to saltwater intrusion. As productivities decline above a threshold of salinity exposure as our synthesis reveals, coastal ecosystems become vulnerable to carbon losses. For example, coastal wetlands with low iron-sulfide buffering and dominant plant species with low sulfide tolerance, as well as those with high stores of carbon and nutrients that are readily exported and transported by land-atmosphere and land-ocean fluxes, are likely among the most vulnerable to sealevel rise and saltwater intrusion ${ }^{4,23}$. Climate may also drive differential metabolic responses to saltwater intrusion and carbon fluxes. Further understanding of how plant-soil-water chemistry drive variable responses to salinity in coastal wetlands is needed.

Continued exposure to saltwater intrusion and climate-driven disturbances may reduce carbon storage capacity of coastal wetland ecosystems as productivity declines at higher salinities. Development of vast belowground stores of carbon in coastal wetlands will depend upon continued production of plant biomass, growth, and accretion and burial of carbon despite changing abiotic stressors (e.g., salinity, sulfidation, inundation, and disturbances) that otherwise may lead to non-linear responses characterized by abrupt and unpredictable degradation of vegetated habitat to open-water states ${ }^{9,10,30}$. Forecasting whether coastal ecosystems continue to develop or transition to another vegetated state (e.g., freshwater marshes to mangroves, tidal freshwater forests to marshes) or to slowly or abruptly decline to open water requires a mechanistic understanding of how saltwater intrusion affects carbon production, storage, and export as sea levels rise ${ }^{31,32}$. This information is necessary to evaluate the longevity of carbon-climate feedbacks and to simplify the processes implemented in the next generation of Earth Systems models ${ }^{33}$.

\section{References}

1. Wang, F. et al. Tidal wetland resilience to sea level rise increases their carbon sequestration capacity in United States. Nature Communications $10,1-11$ (2019).

2. Rogers, K. et al. Wetland carbon storage controlled by millennial-scale variation in relative sea-level rise. Nature 567, 91-95 (2019).

3. Odum, E. P. Finn, J. T. \& Franz, E. H. Perturbation theory and the subsidy-stress gradient. BioScience 29, 349-352 (1979).

4. Herbert, E. R. et al. A global perspective on wetland salinization: Ecological consequences of a growing threat to freshwater wetlands. Ecosphere 6, 143 (2015).

5. Osland, M. J. et al. Beyond just sea-level rise: Considering macroclimatic drivers within coastal wetland vulnerability assessments to climate change. Glob Chang Biol 22, 1-11 (2016).

6. Kirwan, M. L. \& Megonigal, J. P. Tidal wetland stability in the face of human impacts and sea-level rise. Nature 504, 53-60 (2013).

7. Kirwan, M. L. \& Gedan, K. B. Sea-level driven land conversion and the formation of ghost forests. Nat Clim Chang 9, 450-457 (2019).

8. Tully, K. et al. The invisible flood: the chemistry, ecology, and social implications of coastal saltwater intrusion. BioScience 69, 368-378 (2019).

9. Odum, E. P. The strategy of ecosystem development. Science 164, 262-270 (1969).

10. Kominoski, J. S. et al. Advancing theories of ecosystem development through long-term ecological research. BioScience 68, 554-562 (2018).

11. Brown, J. H. et al. Towards a metabolic theory of ecology. Ecology 85, 1771-1789 (2004).

12. Herbert, E. R. et al. Differential effects of chronic and acute simulated seawater intrusion on tidal freshwater marsh carbon cycling. Biogeochemistry 138, 137-154 (2018).

13. Servais, S. et al. Effects of saltwater pulses on soil microbial enzymes and organic matter breakdown in freshwater and brackish coastal wetlands. Estuar Coast 43, 814-830 (2020). 
14. Chambers, L. G. et al. Toward a mechanistic understanding of "peat collapse" and its potential contribution to coastal wetland loss. Ecology $\mathbf{1 0 0 ,}$ e02720 (2019).

15. Silliman, B. R. et al. Field experiments and meta-analysis reveal wetland vegetation as a crucial element in the coastal protection paradigm. Curr Biol 29, 1800-1806 (2019).

16. Charles, S. P. et al. Experimental saltwater intrusion drives rapid soil elevation and carbon loss in freshwater and brackish Everglades marshes. Estuar Coast 42, 1868-1881 (2019).

17. Solohin, E. et al. Declines in plant productivity drive loss of soil elevation in a tidal freshwater marsh exposed to saltwater intrusion. Ecology 101, e03148 (2020).

18. Ardón, M. et al. Drought and saltwater incursion syngeristically reduce dissolved organic carbon export from coastal freshwater wetlands. Biogeochemistry 127, 411-426 (2016).

19. Helton, A. M. et al. Hydrologic context alters greenhouse gas feedbacks of coastal wetland salinization. Ecosystems 22, 1108-1125 (2019).

20. Ardón, M. et al. Salinity effects of greenhouse gas emissions from wetland soils are contingent upon hydrologic setting: a microcosm experiment. Biogeochemistry 140, 217-232 (2018).

21. Stagg, C. L. et al. Direct and indirect controls on organic matter decomposition in four coastal wetland communities along a landscape salinity gradient. J Ecol 106, 655-670 (2017).

22. Craft, C. et al. Forecasting the effects of accelerated sea-level rise on tidal marsh ecosystem services. Front Ecol Environ 7, 73-78 (2009).

23. Schoepfer, V. A. et al. Iron clad wetlands: soil iron-sulfur buffering determines coastal wetland response to saltwater incursion. J Geophys Res: Biogeosci 119, 2209-2219 (2014).

24. Li, F. \& Pennings, S. C. Responses of tidal freshwater and brackish marsh macrophytes to pulses of saline water simulating sea level rise and reduced discharge. Wetlands 38, 885-891 (2018).

25. Osland, M. J. et al. Winter climate change and coastal wetland foundation species: salt marshes versus mangrove forests in the southeastern US. Glob Chang Biol 19, 1482-1494 (2013).

26. Cavanaugh, K. C. et al. Poleward expansion of mangroves in a threshold response to decreased frequency of extreme cold events. Proc Natl Acad Sci 111, 723-727 (2014).

27. Krauss, K. W. et al. Sea-level rise and landscape change influence mangrove encroachment onto marsh in the Ten Thousand Islands region of Florida, USA. J Coast Conserv 15, 629-638 (2011).

28. Breithaupt, J. L. et al. Increasing rates of carbon burial in southwest Florida coastal wetlands. J Geophys Res: Biogeosci 125, e2019JG005349 (2020).

29. Gedan, K. B. \& Fernández-Pascual, E. Salt marsh migration into salinized agricultural fields: a novel assembly of plant communities. J Veg Sci 30 , 1007-1016 (2019).

30. Ratajczak, Z. et al. Abrupt change in ecological systems: inference and diagnosis. Trends Ecol Evol 33, 513-526 (2018).

31. Cherry, J. A. et al. Elevated $\mathrm{CO}_{2}$ enhances biological contributions to elevation change in coastal wetlands by offsetting stressors associated with sea-level rise. J Ecol 97, 67-77 (2009).

32. Morris, J. T. et al. Responses of coastal wetlands to rising sea level. Ecology 83, 2869-2877 (2002).

33. Ward, N. D. et al. Representing the function and sensitivity of coastal interfaces in Earth system models. Nature Communications 11, 1-14 (2020).

34. Kominoski, J. S. Saltwater Coastal Carbon Flux Synthesis ver 1. Environmental Data Initiative.

https://doi.org/10.6073/pasta/27afcea3bab0adc058457705506248f8 (2021).

35. Wood, S. mgcv: mixed GAM computation vehicle with GCV/AIC/REML smoothness estimation. R package version 1.7-22 (2012).

36. Fox, J. \& Weisberg, S. Multivariate linear models in R. An R Companion to Applied Regression. Los Angeles: Thousand Oaks (2011).

37. R Core Team. R: A language and environment for statistical computing. R Foundation for Statistical Computing, Vienna, Austria (2020). URL https://www.R-project.org/ 
38. Wilson, B. J. et al. Salinity pulses interact with seasonal dry-down to increase ecosystem carbon loss in marshes of the Florida Everglades. Ecol. Appl. 28, 2092-2108 (2018).

39. Neubauer, S. C. Ecosystem responses of a tidal freshwater marsh experiencing saltwater intrusion and altered hydrology. Estuar. Coast. 36, 491-507 (2013).

40. Wilson, B. J. et al. Declines in plant productivity drive carbon loss from brackish coastal wetland mesocosms exposed to saltwater intrusion. Estuar. Coast. 41, 2147-2158 (2018).

41. Wilson, B. J. et al. Spatial and temporal variability in carbon dioxide and methane exchange at three coastal marshes along a salinity gradient in a northern Gulf of Mexico estuary. Biogeochemistry 123, 329-347 (2015).

42. Weston, N. B. et al. Accelerated microbial organic matter mineralization following salt-water intrusion into tidal freshwater marsh soils. Biogeochemistry 102, 135-151 (2011).

43. Herbert, E. R. et al. Differential effects of chronic and acute simulated seawater intrusion on tidal freshwater marsh carbon cycling. Biogeochemistry 138, 137-154 (2018).

44. Wilson, B. J. et al. Phosphorus alleviation of salinity stress: effects of saltwater intrusion on an Everglades freshwater peat marsh. Ecology 100, e02672 (2019).

45. Krauss, K. W. et al. Component greenhouse gas fluxes and radiative balance from two deltaic marshes in Louisiana: Pairing chamber techniques and eddy covariance. JGR Biogeosci. 121, 1503-1521 (2016).

46. Tong, C. et al. Greenhouse gas fluxes and porewater geochemistry following short-term pulses of saltwater and Fe(III) in a subtropical tidal freshwater estuarine marsh. Geoderma 369, 114340 (2020).

47. Poffenbarger, H. J., Needelman, B. A. \& Megonigal, J. P. Salinity influences on methane emissions from tidal marshes. Wetlands 31, 831-842 (2011).

48. Morant, D. et al. Carbon metabolic rates and GHG emissions in different wetland types of the Ebro Delta. PLoS ONE 15, e0231713 (2020).

\section{Methods}

Data Collection

We collated published and unpublished data from studies that measured net ecosystem exchange as carbon dioxide $\left(\mathrm{CO}_{2}\right)$ fluxes $\left(\right.$ and methane, $\mathrm{CH}_{4}$, where available) from marshes that varied in surface water and porewater salinity concentrations (both manipulative experiments and observations). We selected studies to minimize the influence of exogenous covariates such as land-use, hydrologic, and water quality changes, but we included studies that had at least a year of data. We calculated minimum, maximum, and median values from time series of gross ecosystem productivity (GEP), ecosystem respiration $\left(\mathrm{ER}_{\mathrm{CO} 2}, \mathrm{ER}_{\mathrm{CH} 4}\right)$, and net ecosystem productivity [NEP = gross ecosystem productivity (GEP) - ecosystem respiration [as carbon dioxide $\left(\mathrm{ER}_{\mathrm{CO} 2}\right)$ and methane $\left(\mathrm{ER}_{\mathrm{CH} 4}\right)$ ]. We chose median metabolic rates from time series from each study as the most conservative metric to compare across the range of diverse marsh ecosystems. We included data that were measured at daily and monthly scales ${ }^{34}$ and converted to daily rates (Table S1). Whenever possible, we used measured porewater salinities. If porewater data were not available, we used measured surface water salinities. We calculated the change in salinity as the difference between ambient and elevated concentrations from experimental salinity additions, or as the differences in observed salinities between freshwater and brackish marshes or freshwater and saltwater marshes. We calculated the \% difference of change in median values of $\mathrm{GEP}, \mathrm{ER}_{\mathrm{CO} 2}, \mathrm{ER}_{\mathrm{CH} 4}$, and $\mathrm{NEP}$ using the following equation:

Percent (\%) Difference in Median $=[($ elevated - ambient $) / \mid$ ambient $\mid] \times 100$

(1)

\section{Data Analyses}

To understand salinity effects on ecosystem metabolism (GEP, ER $\mathrm{CO}_{2}, \mathrm{ER}_{\mathrm{CH} 4}$, and NEP) across diverse marshes, we used generalized additive models (GAM) with the gam function in the "mgcv" package ${ }^{35}$ in R. Generalized additive models use smooth functions to model non-linear functional relationships between predictors and the response. This approach separates linear trends from any general non-linear trends to determine if the significance of a smoothed variable is associated with a simple linear trend or a more complicated pattern. We used Quantile-Quantile (Q-Q) plots of the residuals to evaluate if the appropriate distribution, identity, and log-link were used. The Durbin-Watson statistic, with the durbinWatsonTest function in the "car" package ${ }^{36}$, was used to determine the AR(1) correlation coefficient. We then specified the AR(1) correlation coefficient and used the gam.check function to evaluate the convergence of the smoothness selection optimization and run diagnostic tests to evaluate whether the dimension choices were adequate. We then proceeded by updating the original GAM model. A $P$-value of 0.05 was used to determine the inclusion of salinity as an independent 
variable, and the explanatory powers of the final models were compared using the $R^{2}$ statistic and the percent deviance explained. All statistical analyses were performed in R v.3.6.1 and RStudio v. 1.2.1335 ${ }^{37}$.

Data availability: Data are available in the Environmental Data Initiative repository at https://portal.edirepository.org/nis/mapbrowse?scope=knb-lterfce\&identifier=1231\&revision=1

Code availability: Novel code are available as Supplementary Information.

\section{Declarations}

\section{Author contributions:}

Conceptualization: JSK, SN, KG, RB

Methodology: JSK, SN, RB

Investigation: JSF, SN, RB, AC, DM, ACS

Visualization: JSK, RB

Funding acquisition: All

Project administration: JSK

Supervision: JSK

Writing - original draft: JSK, RB

Writing - review \& editing: All

\section{Acknowledgements}

Ideas for this article were developed by participants of the 2016 First Open Science Meeting of the International LTER (ILTER) Network in Kruger National Park, South Africa, and feedback from the 2017 NSF-LTER MiniSymposium in Arlington, VA, USA. The National Science Foundation and the U.S. Long Term Ecological Research Network provided support for the 2016 ILTER and 2017 MiniSymposium meetings. We also thank the Florida Coastal Everglades and Georgia Coastal Ecosystems Long Term Ecological Research Programs. We also acknowledge funding from the U.S. Geological Survey Climate Research and Development Program. Any use of trade, firm, or product names is for descriptive purposes only and does not imply endorsement by the U.S. Government. We acknowledge the following funding sources: National Science Foundation grant DEB-1237517 (JSK, EE), National Science Foundation grant OCE-9982133 (EH), National Science Foundation grant OCE-0620959 (EH), National Science Foundation grant DEB-1832221 (KG), National Oceanic and Atmospheric Administration, Florida Sea Grant R/C-S-56 (TGT), Agencia Estatal de Investigación de España, PID2019-104742RBI00 (AC, DM, ACS), CLIMAWET-CONS (AC, DM, ACS)

Supplementary Information is available for this paper.

Correspondence and requests for materials should be addressed to JSK (jkominos@fiu.edu).

Reprints and permissions information is available at www.nature.com/reprints.

\section{Table S1}


Table S1

Locations of studies and data used to synthesize cross-ecosystem productivity responses to elevated experimental salinity additions and observational salinity gradients. Median and \% differences were calculated from published and unpublished values (indicated by *) of gross ecosystem productivity (GEP), ecosystem respiration [as $\mathrm{CO}_{2}\left(\mathrm{ER}_{\mathrm{CO} 2}\right)$ and $\mathrm{CH}_{4}\left(\mathrm{ER}_{\mathrm{CH} 4}\right)$ fluxes], and net ecosystem productivity (NEP).

Percent $(\%)$ Difference in Median $=[($ elevated - ambient $) / \mid$ ambient $\mid] \times 100$.

\begin{tabular}{|c|c|c|c|c|c|c|c|c|c|c|c|c|c|c|}
\hline $\begin{array}{l}\text { Location \& } \\
\text { Ecosystem } \\
\text { Type }\end{array}$ & Latitude & Longitude & $\begin{array}{l}\text { Study } \\
\text { type }\end{array}$ & $\begin{array}{l}\text { Salinity } \\
\text { (ppt) }\end{array}$ & $\begin{array}{l}\text { Flux } \\
\text { Units } \\
(\mathrm{g} \mathrm{C} \\
\left.\mathrm{m}^{-2}\right)\end{array}$ & GEP & $\%$ & $\mathrm{ER}_{\mathrm{CO} 2}$ & $\%$ & $\mathrm{ER}_{\mathrm{CH} 4}$ & $\%$ & NEP & $\%$ & Cite \\
\hline \multirow{2}{*}{$\begin{array}{l}\text { Everglades, } \\
\text { Florida, USA } \\
\text { non-tidal } \\
\text { freshwater } \\
\text { marsh }\end{array}$} & 25.435278 & -80.780972 & addition & 0.37 & $d^{-1}$ & 3.95 & 0 & 1.10 & 0 & 0.0023 & 0 & 2.67 & 0 & 38 \\
\hline & 25.435278 & -80.780972 & addition & 2.68 & $d^{-1}$ & 3.02 & -24 & 0.78 & -29 & 0.002 & -15 & 2.15 & -20 & 38 \\
\hline \multirow{2}{*}{$\begin{array}{l}\text { Waccamaw } \\
\text { River, South } \\
\text { Carolina, USA } \\
\text { tidal } \\
\text { freshwater } \\
\text { marsh }\end{array}$} & 33.516667 & -79.083333 & addition & 0.15 & $d^{-1}$ & 18.06 & 0 & 9.16 & 0 & 0.25 & 0 & 8.82 & 0 & 39 \\
\hline & 33.516667 & -79.083333 & addition & 3.33 & $d^{-1}$ & 15.48 & -16 & 7.05 & -23 & 0.1 & -61 & 7.46 & -15 & 39 \\
\hline $\begin{array}{l}\text { Everglades, } \\
\text { Florida, USA }\end{array}$ & 25.220381 & -80.8436 & addition & 10.9 & $d^{-1}$ & 4.56 & 0 & 2.24 & 0 & 0.001 & 0 & 2.54 & 0 & 40 \\
\hline $\begin{array}{l}\text { non-tidal } \\
\text { brackish } \\
\text { marsh }\end{array}$ & 25.220381 & -80.8436 & addition & 15.7 & $d^{-1}$ & 2.46 & -46 & 1.53 & -32 & 0.000 & -75 & 0.70 & -73 & 40 \\
\hline $\begin{array}{l}\text { Weeks Bay, } \\
\text { Alabama, } \\
\text { USA } \\
\text { tidal brackish } \\
\text { marsh }\end{array}$ & 30.448889 & -87.814444 & gradient & 3.94 & $d^{-1}$ & 2.83 & 0 & 5.09 & 0 & 0.001 & 0 & -2.31 & 0 & 41 \\
\hline $\begin{array}{l}\text { Dog River, } \\
\text { Alabama, } \\
\text { USA } \\
\text { tidal brackish } \\
\text { marsh }\end{array}$ & 30.586944 & -88.118056 & gradient & 5.26 & $d^{-1}$ & 1.50 & -47 & 2.64 & -48 & 0.000 & -50 & -0.99 & 57 & 41 \\
\hline $\begin{array}{l}\text { Dauphin } \\
\text { Island, } \\
\text { Alabama, } \\
\text { USA } \\
\text { tidal salt } \\
\text { marsh }\end{array}$ & 30.261944 & -88.116667 & gradient & 24.6 & $d^{-1}$ & 1.62 & -43 & 2.59 & -49 & 0.000 & -50 & -0.95 & 59 & 41 \\
\hline $\begin{array}{l}\text { Delaware } \\
\text { River Estuary, } \\
\text { Delaware, } \\
\text { USA } \\
\text { tidal } \\
\text { freshwater } \\
\text { marsh }\end{array}$ & 39.859181 & -75.173147 & gradient & 0.3 & $d^{-1}$ & 0.95 & 0 & 1.60 & 0 & 0.051 & 0 & -0.32 & 0 & 43 \\
\hline $\begin{array}{l}\text { Delaware } \\
\text { River Estuary, } \\
\text { Delaware, } \\
\text { USA } \\
\text { tidal brackish } \\
\text { marsh }\end{array}$ & 39.859181 & -75.173147 & gradient & 2.91 & $d^{-1}$ & 0.36 & -62 & 0.32 & -80 & 0.077 & 52 & -0.01 & 96 & 43 \\
\hline $\begin{array}{l}\text { Delaware } \\
\text { River Estuary, } \\
\text { Delaware, } \\
\text { USA } \\
\text { tidal brackish } \\
\text { marsh }\end{array}$ & 39.859181 & -75.173147 & gradient & 9.56 & $d^{-1}$ & 1.15 & 21 & 1.00 & -38 & -0.022 & -143 & 0.15 & 147 & 43 \\
\hline
\end{tabular}




\begin{tabular}{|c|c|c|c|c|c|c|c|c|c|c|c|c|c|c|}
\hline $\begin{array}{l}\text { Location \& } \\
\text { Ecosystem } \\
\text { Type }\end{array}$ & Latitude & Longitude & $\begin{array}{l}\text { Study } \\
\text { type }\end{array}$ & $\begin{array}{l}\text { Salinity } \\
\text { (ppt) }\end{array}$ & $\begin{array}{l}\text { Flux } \\
\text { Units } \\
(\mathrm{g} \mathrm{C} \\
\left.\mathrm{m}^{-2}\right)\end{array}$ & GEP & $\%$ & $\mathrm{ER}_{\mathrm{CO} 2}$ & $\%$ & $\mathrm{ER}_{\mathrm{CH} 4}$ & $\%$ & NEP & $\%$ & Cite \\
\hline \multirow{2}{*}{$\begin{array}{l}\text { Altamaha } \\
\text { River, } \\
\text { Georgia, USA } \\
\text { tidal } \\
\text { freshwater } \\
\text { marsh }\end{array}$} & 31.339398 & -81.466683 & addition & 0.26 & $d^{-1}$ & 11.8 & 0 & 8.63 & 0 & 0.74 & 0 & 1.85 & 0 & 43 \\
\hline & 31.339398 & -81.466683 & addition & 2.04 & $d^{-1}$ & 8.5 & -28 & 7.03 & -19 & 0.38 & -48 & 1.47 & -21 & 43 \\
\hline $\begin{array}{l}\text { Everglades, } \\
\text { Florida, USA } \\
\text { (mesocosms) }\end{array}$ & 25.086027 & -80.452157 & addition & 0.44 & $d^{-1}$ & 6.91 & 0 & 1.53 & 0 & & & 5.06 & 0 & 44 \\
\hline $\begin{array}{l}\text { non-tidal } \\
\text { freshwater } \\
\text { marsh }\end{array}$ & 25.086027 & -80.452157 & addition & 9.03 & $\mathrm{~d}^{-1}$ & 7.79 & 13 & 1.3 & -15 & & & 6.32 & 25 & 44 \\
\hline $\begin{array}{l}\text { Salvador } \\
\text { Wildlife } \\
\text { Management } \\
\text { Area, } \\
\text { Louisiana, } \\
\text { USA } \\
\text { tidal } \\
\text { freshwater } \\
\text { marsh }\end{array}$ & 29.85869 & -90.286889 & gradient & 0.23 & $d^{-1}$ & & & 2.4 & 0 & 0.13 & 0 & -0.93 & 0 & 45 \\
\hline $\begin{array}{l}\text { Pointe-aux- } \\
\text { Chenes } \\
\text { Wildlife } \\
\text { Management } \\
\text { Area, } \\
\text { Louisiana, } \\
\text { USA } \\
\text { tidal brackish } \\
\text { marsh }\end{array}$ & 29.85869 & -90.286889 & gradient & 9.15 & $d^{-1}$ & & & 1.18 & -51 & 0.03 & -76 & 0.43 & 146 & 45 \\
\hline \multirow{2}{*}{$\begin{array}{l}\text { Tajiaozhou, } \\
\text { Min River } \\
\text { Estuary, } \\
\text { China } \\
\text { tidal } \\
\text { freshwater } \\
\text { marsh }\end{array}$} & 25.96 & 119.379167 & addition & 0.05 & $d^{-1}$ & & & 1.3 & 0 & 0.10 & 0 & & & 46 \\
\hline & 25.96 & 119.379167 & addition & 3.37 & $d^{-1}$ & & & 1.18 & -9 & 0.06 & -44 & & & 46 \\
\hline $\begin{array}{l}\text { Barataria } \\
\text { Basin, } \\
\text { Louisiana, } \\
\text { USA } \\
\text { tidal } \\
\text { freshwater } \\
\text { marsh }\end{array}$ & 29.463963 & -89.965808 & gradient & 0.4 & $d^{-1}$ & & & & & 0.438 & 0 & & & 47 \\
\hline $\begin{array}{l}\text { Barataria } \\
\text { Basin, } \\
\text { Louisiana, } \\
\text { USA } \\
\text { tidal brackish } \\
\text { marsh }\end{array}$ & 29.463963 & -89.965808 & gradient & 1.8 & $d^{-1}$ & & & & & 0.012 & -100 & & & 47 \\
\hline $\begin{array}{l}\text { Barataria } \\
\text { Basin, } \\
\text { Louisiana, } \\
\text { USA } \\
\text { tidal brackish } \\
\text { marsh }\end{array}$ & 29.463963 & -89.965808 & gradient & 18.1 & $d^{-1}$ & & & & & 0.012 & -97 & & & 47 \\
\hline $\begin{array}{l}\text { Yorktown, } \\
\text { Virginia, ÚSA } \\
\text { tidal brackish } \\
\text { marsh }\end{array}$ & 37.267303 & -76.556615 & gradient & 18.7 & $d^{-1}$ & & & & & 0.003 & 0 & & & 47 \\
\hline $\begin{array}{l}\text { Yorktown, } \\
\text { Virginia, USA } \\
\text { tidal salt } \\
\text { marsh }\end{array}$ & 37.267303 & -76.556615 & gradient & 22.6 & $d^{-1}$ & & & & & 0.002 & -100 & & & 47 \\
\hline
\end{tabular}




\begin{tabular}{|c|c|c|c|c|c|c|c|c|c|c|c|c|c|c|}
\hline $\begin{array}{l}\text { Location \& } \\
\text { Ecosystem } \\
\text { Type }\end{array}$ & Latitude & Longitude & $\begin{array}{l}\text { Study } \\
\text { type }\end{array}$ & $\begin{array}{l}\text { Salinity } \\
\text { (ppt) }\end{array}$ & $\begin{array}{l}\text { Flux } \\
\text { Units } \\
(\mathrm{g} \mathrm{C} \\
\left.\mathrm{m}^{-2}\right)\end{array}$ & GEP & $\%$ & $\mathrm{ER}_{\mathrm{CO} 2}$ & $\%$ & $\mathrm{ER}_{\mathrm{CH} 4}$ & $\%$ & NEP & $\%$ & Cite \\
\hline $\begin{array}{l}\text { Yorktown, } \\
\text { Virginia, USA } \\
\text { tidal salt } \\
\text { marsh }\end{array}$ & 37.267303 & -76.556615 & gradient & 26.3 & $d^{-1}$ & & & & & 0.002 & -100 & & & 47 \\
\hline $\begin{array}{l}\text { River Colne, } \\
\text { United } \\
\text { Kingdom } \\
\text { tidal salt } \\
\text { marsh }\end{array}$ & 51.772783 & 1.043404 & gradient & 25 & $d^{-1}$ & & & & & 0.0007 & 0 & & & 47 \\
\hline $\begin{array}{l}\text { River Colne, } \\
\text { United } \\
\text { Kingdom } \\
\text { tidal salt } \\
\text { marsh }\end{array}$ & 51.772783 & 1.043404 & gradient & 33 & $d^{-1}$ & & & & & 0.001 & 43 & & & 47 \\
\hline $\begin{array}{l}\text { Blackwater } \\
\text { National } \\
\text { Wildlife } \\
\text { Refuge, } \\
\text { Maryland, } \\
\text { USA } \\
\text { tidal brackish } \\
\text { marsh }\end{array}$ & 38.407396 & -75.981606 & gradient & 12 & $d^{-1}$ & & & & & 0.067 & 0 & & & 47 \\
\hline $\begin{array}{l}\text { Blackwater } \\
\text { National } \\
\text { Wildlife } \\
\text { Refuge, } \\
\text { Maryland, } \\
\text { USA } \\
\text { tidal brackish } \\
\text { marsh }\end{array}$ & 38.407396 & -75.981606 & gradient & 13 & $d^{-1}$ & & & & & 0.07 & 4 & & & 47 \\
\hline $\begin{array}{l}\text { Ebro River } \\
\text { Delta, Spain } \\
\text { micro-tidal } \\
\text { freshwater } \\
\text { marsh }\end{array}$ & 40.663111 & 0.703076 & gradient & 1.3 & $d^{-1}$ & 2.22 & 0 & 1.58 & 0 & 0.013 & 0 & 2.62 & 0 & 48 \\
\hline $\begin{array}{l}\text { Ebro River } \\
\text { Delta, Spain } \\
\text { micro-tidal } \\
\text { salt marsh }\end{array}$ & 40.638078 & 0.743148 & gradient & 30.4 & $d^{-1}$ & 1.23 & -45 & 1.47 & -7 & 0.002 & -85 & 0.97 & -63 & 48 \\
\hline $\begin{array}{l}\text { Everglades, } \\
\text { Florida, USA } \\
\text { (mesocosms) }\end{array}$ & 25.086027 & -80.452157 & addition & 0 & $d^{-1}$ & 35.17 & 0 & 9.46 & 0 & & & 27.1 & 0 & $\star$ \\
\hline \multirow{2}{*}{$\begin{array}{l}\text { non-tidal } \\
\text { freshwater } \\
\text { marsh }\end{array}$} & 25.086027 & -80.452157 & addition & 5 & $d^{-1}$ & 24.05 & -32 & 5.76 & -39 & & & 19.12 & -29.4 & * \\
\hline & 25.086027 & -80.452157 & addition & 10 & $d^{-1}$ & 27.22 & -23 & 7.39 & -22 & & & 20.68 & -23.7 & * \\
\hline $\begin{array}{l}\text { Pamunkey } \\
\text { River, } \\
\text { Virginia, USA }\end{array}$ & 37.562553 & -76.888451 & addition & 0.12 & $d^{-1}$ & 19.79 & 0 & 8.58 & 0 & 0.27 & 0 & 9.81 & 0 & $\star$ \\
\hline $\begin{array}{l}\text { tidal } \\
\text { freshwater } \\
\text { marsh }\end{array}$ & 37.562553 & -76.888451 & addition & 1.94 & $d^{-1}$ & 13.98 & -29 & 5.56 & -35 & 0.19 & -27 & 7.57 & -22.8 & * \\
\hline
\end{tabular}

\section{Figures}




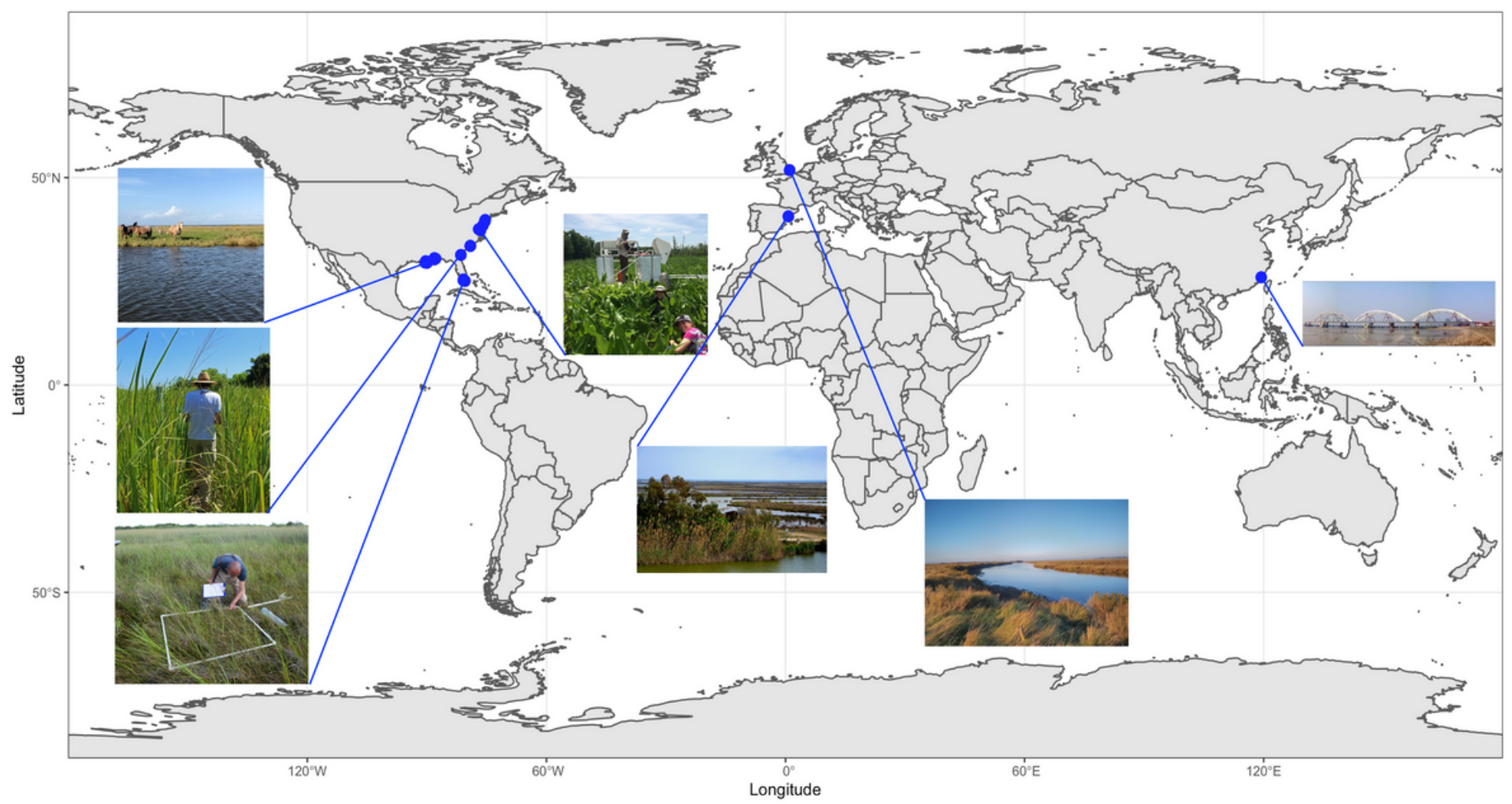

Figure 1

Study locations. Map of the site locations from which data were collected for use in this synthesis. Photo credit (counter clockwise from left: https://www.reddit.com/r/Louisiana/, Erika Zambello, Luca Marazzi, Scott Neubauer, Angela Llop, Bob Seago, https://cn.arch-bridges.fzu.edu.cn/).
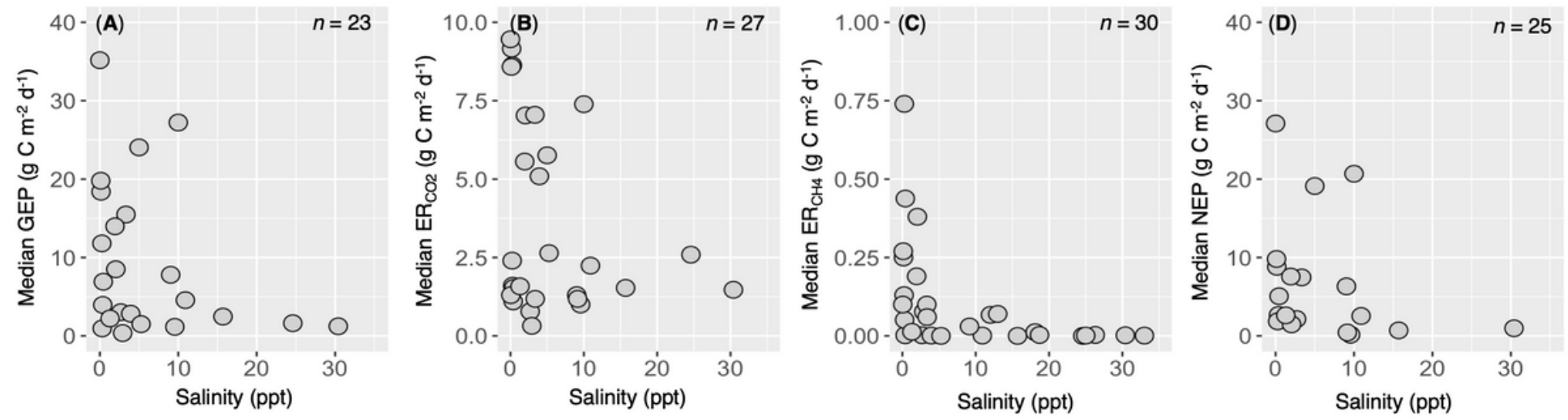

Figure 2

Marsh ecosystem metabolism and salinity. Variation in the long-term median of daily marsh ecosystem metabolism along gradients of salinity. (A) gross ecosystem productivity (GEP), (B) ecosystem respiration (ER) as CO2 (ERCO2), (C) ecosystem respiration as $\mathrm{CH} 4$ (ERCH4) and (D) net ecosystem productivity (NEP) from across time series data from experimental salinity additions and observational salinity gradients (n represents number of time series datasets). 

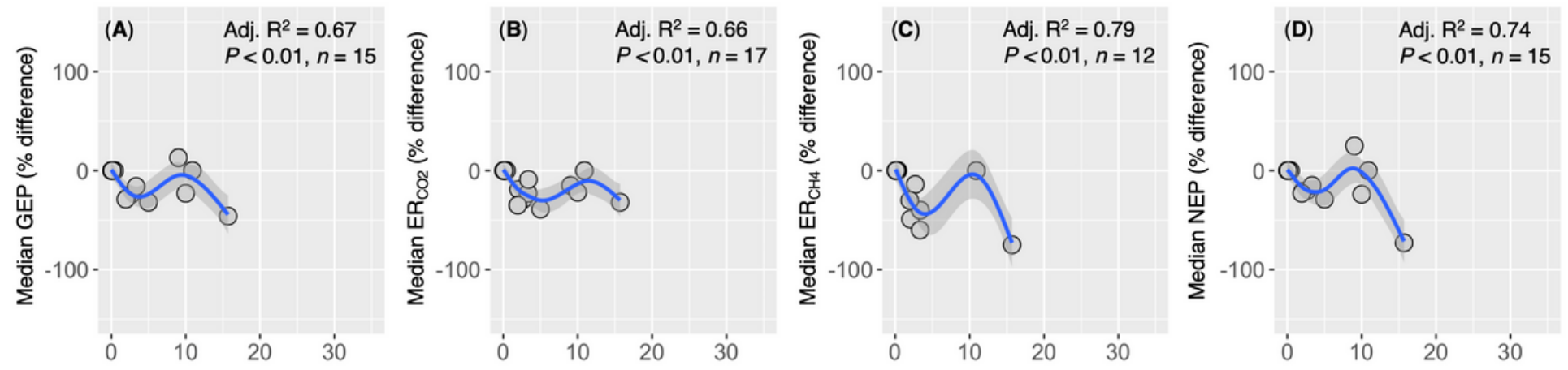

Observational Salinity Gradients
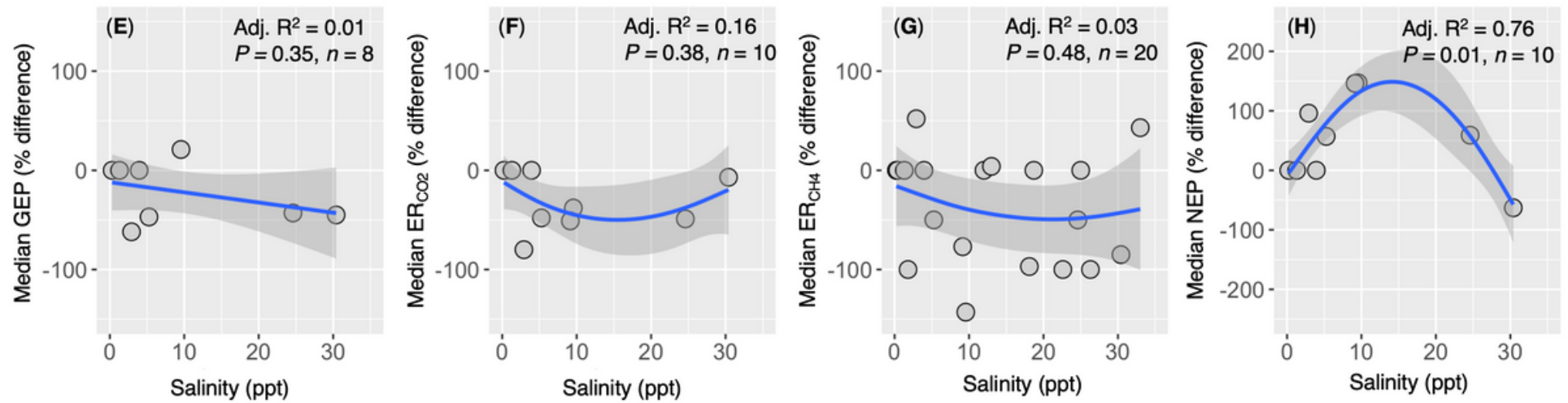

Figure 3

Percent differences in ecosystem metabolism from experimental salinity additions and observational salinity gradients. Generalized additive model predictions, and the effect of smoothed salinity concentrations (ppt) on the percent (\%) difference of the long-term median of daily (A, E) gross ecosystem productivity (GEP), (B, F) ecosystem respiration (ER) as $\mathrm{CO} 2$ (ERCO2), (C, G) ecosystem respiration as $\mathrm{CH} 4$ (ERCH4) and (D, H) net ecosystem productivity (NEP) from across time series data from experimental salinity additions and observational salinity gradients (n represents number of time series datasets). Sample size refers to the number of long-term datasets.
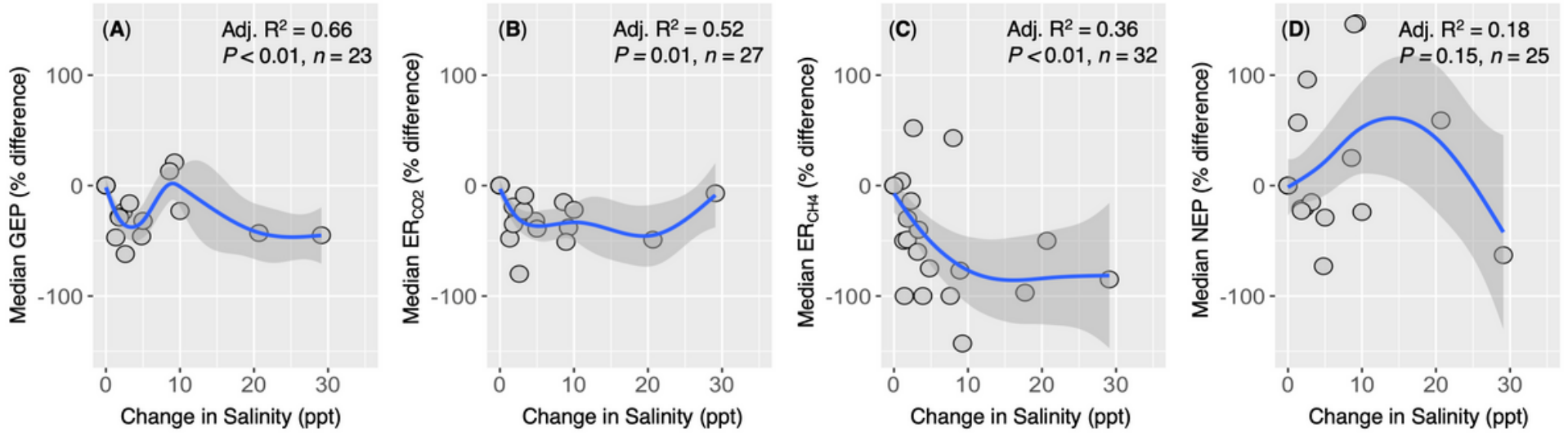

Figure 4

Percent differences in ecosystem metabolism per increase in salinity across all studies. Generalized additive model predictions, and the effect of smoothed salinity concentrations (ppt) on the percent (\%) difference of the long-term median of daily (A) gross ecosystem productivity (GEP), (B) ecosystem respiration (ER) as $\mathrm{CO} 2$ (ERCO2), (C) ecosystem respiration as $\mathrm{CH} 4$ (ERCH4) and (D) net ecosystem productivity (NEP) from across time series data from experimental salinity additions and observational salinity gradients (n represents number of time series datasets). 


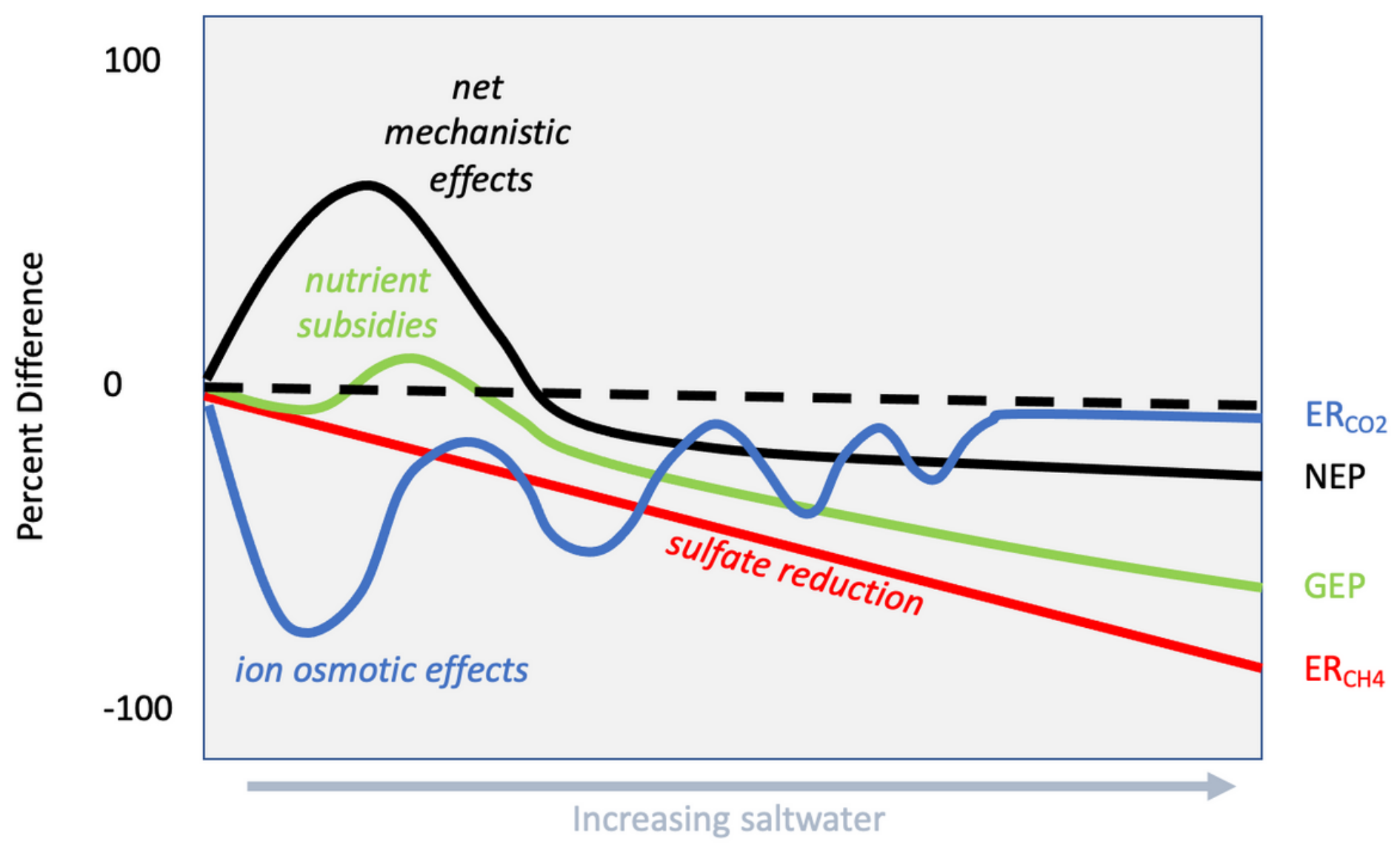

Figure 5

Predicted mechanisms of saltwater intrusion effects on ecosystem metabolism. Conceptual illustration of predicted mechanisms driving observed response patterns of gross ecosystem productivity (GEP), ecosystem respiration (ER) as $\mathrm{CO} 2$ (ERCO2) and $\mathrm{CH} 4$ (ERCH4), and net ecosystem productivity [NEP = gross ecosystem productivity (GEP) - ecosystem respiration [as carbon dioxide (ERCO2) and methane (ERCH4)] in marshes exposed to increasing saltwater.

\section{Supplementary Files}

This is a list of supplementary files associated with this preprint. Click to download.

- salinity.C.flux.090621.txt 